\title{
Determinant factors affect Tourist Satisfaction towards Traditional Balinese Cuisine at Restaurants in Ubud Tourism Resorts, Gianyar, Bali
}

\author{
I Nyoman Arcana ${ }^{1}$, I Nyoman Wiratnaya ${ }^{2}$ and Ni Putu Ariesta Budiani ${ }^{3}$ \\ ${ }^{12}$ Sekolah Tinggi Pariwisata Nusa-Dua Bali \\ Email: ${ }^{1}$ nyoman.arcana@yahoo.com, ${ }^{2}$ inwiratnaya@yahoo.com and ${ }^{3}$ ariestabud@gmail.com
}

\begin{abstract}
Bali has various types of traditional food dishes as local products that attract tourists. Local Balinese culinary arts offer a gastronomic experience of local cuisine that has a distinctive taste. The local processed ingredients, the presentation, and the exciting flavors become value added of local cuisine, so the taste of local cuisine is generally accepted by tourists. The uniqueness of taste, processing, presentation and service quality of traditional Balinese cuisine will enhance the image of Bali's culinary destinations, especially in Ubud Tourism Area, Gianyar. This study aims to examine the performance and factors that affect tourist satisfaction on traditional Balinese cuisine at restaurant in Ubud Tourism Area. The variables measured in this study are: 1) Quality of food (Food Quality / reliability); 2) Price; 3) Food hygiene; and 4) Dining atmosphere. The study found that traditional Balinese cuisine have excellent rating (quality of cuisine and eating atmosphere) and good rating (price and food hygiene). Furthermore, this study found the determinants factors affect tourist satisfaction towards traditional Balinese cuisine at restaurant can be classified into two groups, consist of the high importance level (the unique taste of traditional Balinese cuisine (aroma, portion size, presentation, value for money, cleanliness of presentation, cleanliness of the processing, use of raw materials, dining design and privacy), and low importance level (menu diversity, affordable traditional cuisine prices, available special package pricing, promotional packages available, free wifi access and music dining room atmosphere). This research recommends restaurants that sell traditional Balinese cuisine in Ubud Tourism Area to offer more menu choices, create special package prices, create more promotional packages, improve the hygiene\&cleanliness in cooking process, and provide free wifi network facilities.
\end{abstract}

Keywords—-tourist satisfaction, restaurant, traditional Balinese cuisine, Ubud Tourism Area.

\section{INTRODUCTION}

Gianyar Regency has the potential of a very interesting tourist attraction to visit, be it cultural attractions, archaeological history, and the beauty of nature. Gianyar regency also has traditional food culinary attraction as tourist attraction, such as Chicken Betutu and Duck Betutu, crispy duck, satay lilit, lawar kacang panjang, yellow rice, kelepon, and etc. The culinary tourism offers a gastronomic experience of local cuisine that has a distinctive taste. The local processed ingredients, the presentation of the cuisine, and the appealing taste that appeals to the tastes of tourists also add value to the local cuisine, so the taste of local cuisine is generally accepted by tourists. There are a variety of restaurants serving international cuisine or cuisine at the Ubud Tourism Area, Gianyar, however, not a few tourists choose to enjoy the sensation of local cuisine as their favorite food. This is due to several things, such as the historical value of the place to eat, the typical local cuisine, and the sense of cuisine that can be accepted by tourists.

Gastro-tourism or culinary tourism can attract millions of tourists and provide significant revenue for the destinations visited. Gastro-tourism create a specific tourist attraction to explore the experience of enjoying regional specialties during the tour trips in the area. Food and drink is one of the basic human needs that must be consumed continuously, including when traveling. Therefore, culinary arts or gastronomy is one of the attractions that can attract tourists to a destination. Furthermore, gastronomy and culinary arts are often a package of travel programs offered by travel agencies in addition to accommodation packages and other attractions.

Food is one of the main implicit factors considered by travelers in choosing a destination. As revealed by Lacy and Douglass which states "every tourist is a voyeuring gourmand". Food-related research, beverages, cuisine, culinary conditions and gastronomy have been subjected to studies in the 
sub-fields of sociology and anthropology. Currently there is a lot of literature and internet studies on culinary/gastronomic arts related to the attraction of destinations, especially in destinations in countries whose tourism sector is already developing or developing such as Thailand, Malaysia, Vietnam and Indonesia.

In general, the product of a restaurant is food, drink, service, souvenir, atmosphere, and entertainment. Food and beverage factors consist of menu types, variations of menu choice, taste, texture, and presentation, while service factor consists of choice of service, reservation or seating, payment by credit card, availability of portion size, access to health information, availability of chairs for babies. Hygiene factors consist of staff grooming, cleanliness of employee uniforms, clean and neat menu lists, proper food \& drink presentation temperature, handglove use for kitchen staff, cleanlines of cutlery \& tableware, and cleanliness of the whole area, while the price factor consists of the value for money that gained by the customer (Cousins at all: 2002). Furthere more, the atmospheric factor consists of design, decoration, lighting, air conditioning, furnishing, noise level, guest behavior of guests, and employee behavior. The atmosphere in food and beverage operation divided into the viewed, heard, touched, felt and smelled atmosphere.

In the restaurant industry there are several factors that influence consumer loyalty, such as (1) the special benefits for loyal customers; (2) the convenience of a place; (3) location of restaurant close to residence or work office; (4) recommendations from friends; (5) the location of the restaurant is close to popular places; (6) the performance of restaurant staff who are always ready to help customers; (7) design / menu language that is easy to read and understand; (8) a special price on a particular menu on certain days; (9) a menu suitable for health; (10) the availability of popular menu options; (11) ease in obtaining compensation for dissatisfaction(Moschis at all: 2003).

The characteristic of traditional Balinese cuisine can be seen from the menu products offered by the restaurant that distinguish it from European cuisine or certain typical country cuisine, such as the name of cuisine, the way of processing cuisine, the use of local or domestic spices as flavor, and the use of local ingredients. Some examples of traditional Balinese cuisine are generally sold in restaurants in Ubud area such as Ayam or Bebek Betutu, Grilled Fish with Sambal Matah, Crispy Duck, Sate Lilit, Gerang Asem, Nasi Campur and Chicken Bumbu Pelecing. Likewise, the main dish consisting of Urap Sayur, Yellow Rice, Sambal Embe, Sambal Matah, Sambal Bongkot and etc.

\section{A. Research Question}

Based on the description of the background, then the research question in this study are:

1. What is the determinant factor affect tourist satisfaction at traditional Balinese cuisine at restaurant in Ubud, Gianyar?

2. How is overall tourist satisfaction towards traditional Balinese cuisine at restaurant in Ubud, Gianyar?

3. What factors dominantly influence the tourist satisfaction?

4. What factors has not been appropriate, is appropriate, or exceeds the expectations?

\section{B. Research Objectives}

The general objective of this study is to assess the performance and factors that influence the satisfaction of tourists towards traditional Balinese cuisine at restaurant in Ubud, Gianyar.

\section{LITERATURE REVIEW}

in the tourism resorts, restaurants has a significant role in determining the destination choice of travelers. Around $20 \%$ of the tourists who visited the tourist area for the first time agreed that the restaurant plays a very important role in the selection of tourist destinations. While $46 \%$ of travelers who have received positive experiences in restaurants in the tourist destination area agree to return to visit the next opportunity. This caused by the reason for being able to re-enjoy the service in the same restaurant (Sparks at all: 2003).

Three important things in restaurant industry that can be used as a reference by tourists to visit again. These three references are perceived quality, perceived value, and perceived satisfaction which are fundamental guidelines for building consumer loyalty to restaurant products [4]. A restaurant should develop a strategy of setting a different selling price for each different food groups, at different meals each day and on different days each week [4]. The most influential factor in determining the 
satisfaction of tourists is service quality, followed by restaurant atmosphere, cleanlines and hygiene, food and beverage, and price (Suastuti: 2011).

There was a positive relationship between place variables (place / ambiance) and service quality to restaurant's customer satisfaction (Abdullah: 209). Pun and Ho 2001 in measured customer satisfaction variables on restaurants based on variables: 1) Competitive Location; 2) Prices; 3) Food Quality; and 4) Customer Service. On the other hand, to measure restaurant customer satisfaction, some variables, such as: First \& Last Impressions, Service Excellence, Ambiance Excellence, Food Excellence, Feeling Comfortable Eating There, and Reservation \& Parking are very important (Kivela: 1997).

Satisfaction is the individual perception of the performance of a product or service associated with their expectations of the product or service itself. The concept of satisfaction is a function or usefulness of expectation. Customers who get product performance lower than expectation then the customer will not satisfied. Customers who get the same product performance with expectations then they will be satisfied, while those who get product performance exceed expectations will be very satisfied (Bozorgi: 2007). In general, the measurement of customer satisfaction level using five levels or five-point scale, consist of: very satisfactory, satisfactory, indifferent, less satisfactory, very less satisfactory (Bozorgi : 2007).

The measured customer satisfaction is the satisfaction of each service component and overall satisfaction. Tourist satisfaction is part of consumer behavior. According to Supranto (2001) the field of consumer behavior is in the development of marketing science, based from the concept of marketing with the orientation of product concepts, production concepts and sales concepts. While quality is the accumulation of satisfaction a group of consumers to their experiences of the service received. The service is the similarity to the perception of a single service received and measured in proportion to the expected customer expectation of the received servic. There are six factors that become the motivator of tourists to choose restaurants in tourist destinations, namely: indulgence, comfort and relaxation (comfort and relaxation), experience, social reason, adventure, and health (Sparks at all: 2003). Factors that influence consumer decisions to choose a restaurant are: food and drink offered (food and drink on offer); level of service level; level of cleanliness and hygiene; the feasibility of satisfaction derived from the money spent (perceived value for money and price); and the atmosphere and comfort of the restaurant (Cousins at all: 2002).

\section{A. Factors Affecting Restaurant Consumer Satisfaction}

A restaurant concept consists of five elements: menu, food production strategy, service / service, price, and decoration or atmosphere (Dogdubay and Avcikurt: 2008). On the other hand, the use variables Food Quality, Service Quality, Ambiance, Convenience, and Overall (everything included) as variables or factors that affect restaurant customer satisfaction as important as variables food quality / reliability, responsiveness, physical design, and price. Restaurant managers use the factors of food quality, customer service, competitive location, and price as well as factors of food excellence, service excellence, ambience excellence, first and last impressions, feeling comfortable eating there, and reservation \& parking (Kivela: 1997).

\section{B. Traditional Balinese Cuisine}

The existence of traditional Balinese food still be recognized and need to be preserved while seen from its essence as supporting culinary tourism in Badung regency, Bali. There are seven criteria of Balinese food, such as: the taste of food and beverages, presentation, and service, the higyene and sanitation, the speed of order handling, and supporting facilities, and prices offered (Putri: 2010).

Strengths aspect in marketing strategies of traditional Balinese food at restaurant were food and beverage quality, food and beverage portion size, menu design, menu composition, nutrition and health, menu presentation, restaurant atmosphere, food and beverage prices, discounts on certain guests, "happy hours" application, restaurant popularity level, restaurant location, access and ease to reach restaurant, service quality, promotion intensity by restaurant waitresses, the creativity of special packages, the attitude and appearance of restaurant employees, restaurant-oriented restaurant staff, cooperation with restaurant businesses, and alliances with other tourism businesses (Dalem: 2010).

A study entitled Safety of Balinese ethnic foods found that Balinese ethnic foods were traditionally produced by mixing specific spices. This traditional processing method can create a specific and distinctive taste, but this traditional processing process makes Balinese ethnic foods identified to contain microorganisms beyond the limits amount permitted by local government 
regulations. This can be dangerous because it can cause foodborne diseases. The findings of this study suggest that ethnic Balinese food processing should be done more hygienically, using quality ingredients, and using clean tools in its processing is expected to cope with this problem (Sujaya: 2013).

Traditional Balinese cuisine is a food that is processed and made by local people from generation to generation using a combination of local flavor (base) that has a taste and a specific aroma that is not owned by other regions. In general, consumers assess a food product of four variables, among others: food / menu variables, price, cleanliness, and the atmosphere of where to eat. This study aims to determine the satisfaction of tourists toward traditional Balinese cuisine at restaurant in Ubud Tourism Area. Traditional Balinese cuisine is Bali's culinary treasure that needs to be maintained, developed, and used as a tourist attraction.

In general, consumers assess a food product of four variables, among others: food / menu variables, price, cleanliness, and the atmosphere of where to eat. Some indicators to assess traditional Balinese cuisine include: a). the uniqueness of the taste of food, b). aroma of food, c). portion sizes of food, d). choice / menu diversity, e). prentasi / display food, f). Affordable price, g). the existence of special packages such as frugal packages, $\mathrm{h}$ ). the existence of promotional packages like buy one free one, i). value for money (the price paid according to what is obtained, $\mathrm{j}$ ). food serving hygiene, $\mathrm{k}$ ). cleanliness of food processing, l). use of quality raw materials, clean, and safe for health, $\mathrm{m}$ ) dining design, n). level of noise, o) breadth of food, p). the presence of additional facilities such as wifi, music.

\section{METHODS}

To answer the research question posed in the previous page primary data are needed. The data would be collected by a questionnaire. This study uses four variables with 16 indicators consisting of: 1. Variable food / menu with five indicators: a). the uniqueness of the taste of food, b). aroma of food, c). portion sizes of food, d). choice / menu diversity, e). prentasi / appearance of food. 2. Variable food prices consisting of four indicators, among others: a). Affordable prices, b). the existence of special packages such as frugal packages, c). the existence of promotional packages such as buy one free one, d). value for money (the price paid in accordance with what is obtained) 3 . Hygiene and sanitation variables with three variables are: a). hygiene of food presentation, b). cleanliness of food processing, c). the use of quality raw materials, clean, and safe for health. 4. Variable atmosphere where to eat with four variables, among others: a) design a place to eat, b). the level of noise, c) the extent of food, d). the presence of additional facilities such as wifi, music.

\section{A. Population, Samples and Sampling}

The population in this research is all the tourists in Ubud Tourism Area which become the customer of traditional Balinese cuisine restaurant. Samples are some of the objects drawn from the population where their characteristics will be investigated and are considered to represent the entire population of concern in the study (Pramesti, 2006). The sample in this study were the tourists who became the respondents at fifteen (15) fruits restaurant selling traditional Balinese cuisine in Ubud Tourism Area. The sampling technique used in this research is the Non-Probability Sampling method, ie sampling technique where there is no equal opportunity for the selected population member as the sample. In this study determined that the samples in the study are tourists who have never enjoyed traditional Balinese cuisine in restaurants or restaurants in the Ubud Tourism Area.

\section{B. Research Design}

This research was designed by distributing questionnaires to 60 tourists who had been enjoying traditional Balinese cuisine at restaurant in Ubud Tourism Area between August and October 2017. The questionnaire was so designed that consists of two pages, anonymous, and self-administered. By such design it is hoped that it will be easily and conveniently filled up by the respective respondents. Questionnaire consists of two parts: demographic of respondent (age, gender, address, and education). The second section contains about four variables measured in this study with a total of 16 indicators.

\section{Data Collection Method}

Data collection in this study used questionnaires distributed to tourists who had enjoyed traditional Balinese food at Restaurant in Ubud, Gianyar. Respondents simply choosed and marked the blank on 
the five provided scales ie 1 for very bad, 2 for bad, 3 for enough, 4 for good and 5 for very good (five catagories). This research is a qualitative research with data source in the form of primary data. Data obtained directly through the research process such as sourced from questionnaires.

\section{Research Model}

Model in this research can be seen in figure 1 underneath:

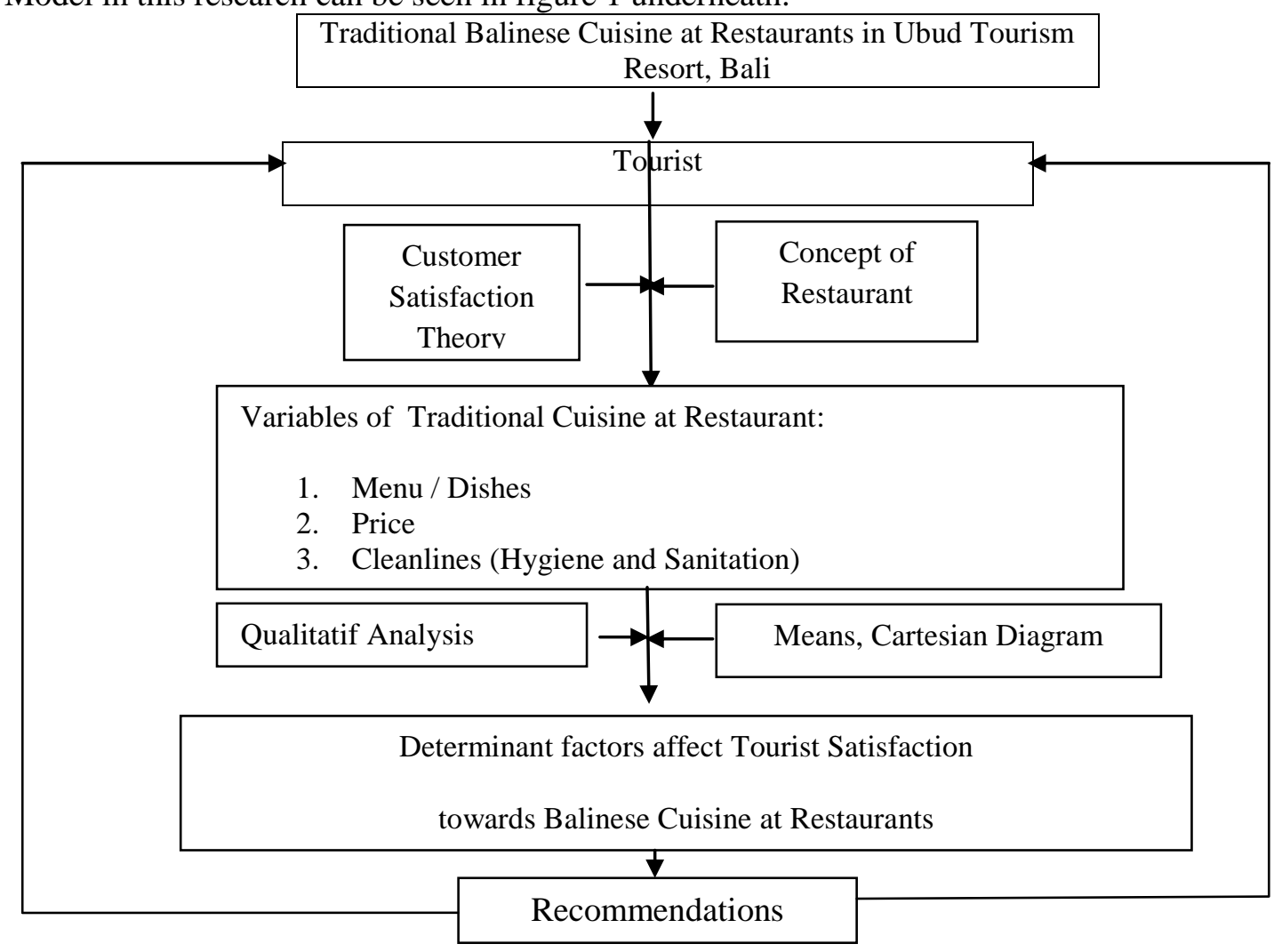

\section{FIG I. RESEARCH MODEL}

The definition of Operational variables in this study listed in Table I underneath:

TABLE I. OPERATIONAL VARIABLES

\begin{tabular}{|c|c|c|c|c|}
\hline No. & Variable & Code & Operasional Definition & Indicator \\
\hline 1. & Food Quality & $\mathrm{X} 1$ & $\begin{array}{l}\text { traditional Balinese menu } \\
\text { menu sold in restaurants }\end{array}$ & $\begin{array}{ll}\text { 1. } & \text { The unique taste } \\
\text { 2. The flavors or aroma } \\
\text { 3. Portion size } \\
\text { 4. The selection of menu choices } \\
\text { 5. Food presentation }\end{array}$ \\
\hline 2. & Price & $\mathrm{X} 2$ & $\begin{array}{l}\text { Price is the value paid for } \\
\text { obtaining traditional } \\
\text { Balinese cuisine }\end{array}$ & $\begin{array}{l}\text { 1. Affordable price offered } \\
\text { 2. The presence of special package food } \\
\text { prices such as cheap price packages } \\
\text { 3. The special offer of promotional } \\
\text { packages such as "buy one get one free" } \\
\text { 4. Value for money }\end{array}$ \\
\hline 3. & $\begin{array}{l}\text { Cleanlines } \\
\text { (hygiene and } \\
\text { sanitation) }\end{array}$ & $\mathrm{X} 3$ & $\begin{array}{l}\text { Hygienic preparation, } \\
\text { processing, and presentation } \\
\text { of traditional Balinese } \\
\text { cuisine }\end{array}$ & $\begin{array}{l}\text { 1. Hygiene presentation and serving } \\
\text { 2. Hygiene preparation and cooking process } \\
\text { 3. Good quality, clean, and selected raw } \\
\text { materials and spices. }\end{array}$ \\
\hline 4. & $\begin{array}{l}\text { The atmosphere } \\
\text { of restaurant }\end{array}$ & $\mathrm{X} 4$ & $\begin{array}{l}\text { The overall effect of } \\
\text { aesthetics and emotions } \\
\text { created through the } \\
\text { atmosphere of dining area }\end{array}$ & $\begin{array}{l}\text { 1. Design of dining area } \\
\text { 2. Privacy and noise levels } \\
\text { 3. Atmosphere of the dining room } \\
\text { 4. Additional facilities such as free wifi } \\
\text { access and music }\end{array}$ \\
\hline
\end{tabular}

Sources : [5], [12], [13], [14]. 
To analyze the level of importance and assessment of tourists on the performance of the factors that determine the satisfaction, the Quantitative Descriptive Analysis is used, such as Interest Rate Analysis and Customer Performance or Important-Performance Analysis (James, et al. 1977, in Supranto, 2001). Cartesian Diagram used to analyse Customer Satisfaction index in ImportantPerformance Analysis.

\section{RESULTS AND DISCUSSION}

\section{A. Characteristics of Respondents}

Based on the result of questionnaire tabulation, the characteristics of respondents according to gender consisted of 36 female $(60 \%)$ and 24 male $(40 \%)$. Based on the nationality, respondents's origin shown as presented in Table II underneath.

TABLE II. RESPONDENTS BASED ON COUNTRY OF ORIGIN

\begin{tabular}{ccc}
\hline Nationality & Number & $\begin{array}{c}\text { Percentage } \\
(\%)\end{array}$ \\
\hline Indonesia & 19 & 31,67 \\
Japan & 12 & 20,00 \\
Australia & 10 & 16,67 \\
China & 4 & 0,70 \\
Holland & 4 & 0,70 \\
Singapore & 3 & 0,50 \\
India & 2 & 0,03 \\
Germany & 2 & 0,30 \\
United States & 2 & 0,30 \\
Malaysia & 2 & 0,30 \\
Total & 60 & 100,00 \\
\hline
\end{tabular}

Sources : Research Questionnaires (2017)

Based on the occupation, there are four groups of respondent's occupations: employees, employers, professionals, students and others, as shown in Table III underneath.

\begin{tabular}{lcc} 
TABLE III. CHARACTERISTICS OF RESPONDENTS BY OCCUPATION \\
\cline { 2 - 3 } \multicolumn{1}{c}{ Occupation } & Number & $\begin{array}{c}\text { Percentage } \\
(\%)\end{array}$ \\
\hline Employee & 34 & 56,67 \\
Businessman & 5 & 0,83 \\
Professional & 9 & 15,00 \\
Student & 6 & 10,00 \\
Retired & 4 & 0,67 \\
Others (housewife) & 2 & 0,33 \\
$\quad$ Total & 60 & 100,00 \\
\hline Sources : Research Questionnaires (2017)
\end{tabular}

Furthermore, based on the purpose of visit, there are three objectives of respondents to visit Bali, consists of 11 business visits (18.33\%), 41 pleasure (68.33\%), and 8 people (13.33\%)for attending seminars. In terms of number of visits to Bali, shows the characteristics of respondents that mostly for the first time visiting Bali, consists of 31 people (51.67\%), then 14 people or $23.33 \%$ visited Bali four times or more 10 people (16.67\%)visited Bali twice, and 5 people (8.33\%) visited three times.

\section{B. Research Locus}

Questionnaires were distributed to fifteen restaurants in Ubud tourism area using purposive sampling method. This purposive sampling method was choosen with the consideration that researchers obtained permission from the restaurant manager to distribute the questionnaires. In each restaurant distributed five of questionnaires to be filled by restaurant's customers. The locus of research where the questionnaire is distributed can be seen in Table IV underneath: 
TABLE IV. RESEARCH LOCUS

\begin{tabular}{lll}
\hline No. & \multicolumn{1}{c}{ Restaurant } & \multicolumn{1}{c}{ Address } \\
\hline 1 & Mr. Wayan, Balinese Cuisisne & Jl. Suweta, Banjar Bentuyung, Ubud \\
2 & Kayun Restaurant \& Lounge & Jl. Raya Mas no. 47 Mas, Ubud \\
3 & Warung Laba Laba & Jl. Hanoman 49 Padang Tegal, Ubud \\
4 & Warung Pondok Madu & Jl. Sugriwa-Sukmakesuma, Padang Tegal, Ubud \\
5 & Kepitu Restaurant (The Kayon Ubud) & Br. Kepitu, Kendran, Tegalalang \\
6 & Warung Titi & Jl. Tirta Tawar, Banjar Kutuh Kaja, Ubud \\
7 & Putu's Wild Ginger & Jl. Jero Gadung, Br. Kutuh kelod, Ubud \\
8 & Sweet Orange Warung & Jl. Subak Juwuk Manis, Banjar Ubud Kaja \\
9 & Warung Bintang Bali & Jl. Tirta Tawar, Junjungan, Ubud \\
10 & Bebek Tebasari Resto & Jl. Raya Kengetan, Lod Tunduh, Ubud \\
11 & Puspa's Warung & Jl. Gootama Selatan No. 22 Ubud \\
12 & Murni's Warung & Jl. Raya Ubud-Campuhan, Ubud \\
13 & Bebek Tepi Sawah & Jl. Goa Gajah, Br. Tges Kangin, Peliatan, Ubud \\
14 & Bebek Bengil & Jl. Hanoman, Padang Tegal, Ubud \\
15 & Nasi Ayam Kedewatan Ibu Mangku & Jl. Kayu Jati No. 12, Kedewatan, Ubud \\
\hline
\end{tabular}

Sources : Research Questionnaires (2017)

All of restaurant mentioned in Table 5 offers Asian dishes, Indonesian dishes, traditionale Balinese dishes, vegetarian and vegan option, such as Ayam Betutu, Bebek Tutu, Nasi Kuning, Ikan Bakar Sambal Matah, Lawar Kenus, Gurita Suna Cekuh, Udang Mebase Bongkot, Nasi Goreng Bongkot, Serapah Kambing, Pulung Be Pasih dan Be Pasih Sambal Kecicang, Sate Lilit, Black Rice Porridge, Pisang Goreng and also healthy drinks.

\section{Performance of Traditional Balinese Cuisine at Restaurant in Ubud Tourism Area.}

Based on data analysis, average performance of traditional Balinese Cuisine at restaurant decsribed in Table $\mathrm{V}$ as follows.

TABLE V. AVERAGE PERFORMANCES

\begin{tabular}{|c|c|c|c|c|c|}
\hline No. & Variable & Mean & Indicator & Mean & Catagory \\
\hline \multirow[t]{5}{*}{1.} & Food & 4,24 & 1. The unique taste & 4,33 & Very good \\
\hline & Quality & (good) & 2. The flavors or aroma & 4,08 & Good \\
\hline & & & 3. Portion size & 4,16 & Good \\
\hline & & & 4. The selection of menu choices & 4,19 & Good \\
\hline & & & 5. Food presentation & 4,45 & Very good \\
\hline \multirow[t]{4}{*}{2.} & Price & 3,40 & 1. Affordable price offered & 3,98 & Good \\
\hline & & (Neutral) & $\begin{array}{l}\text { 2. The presence of special package } \\
\text { food prices such as cheap price } \\
\text { packages }\end{array}$ & 2,78 & Neutral \\
\hline & & & $\begin{array}{l}\text { 3. The special offer of promotional } \\
\text { packages such as "buy one get } \\
\text { one free" }\end{array}$ & 2,57 & $\mathrm{Bad}$ \\
\hline & & & 4. Value for money & 4,33 & Very good \\
\hline \multirow[t]{3}{*}{3.} & $\begin{array}{l}\text { Cleanlines } \\
\text { (hygiene and }\end{array}$ & $\begin{array}{c}4,17 \\
\text { (good) }\end{array}$ & $\begin{array}{l}\text { 1. Hygiene presentation and } \\
\text { serving }\end{array}$ & 4,28 & Very good \\
\hline & sanitation) & & $\begin{array}{l}\text { 2. Hygiene preparation and } \\
\text { cooking process }\end{array}$ & 4,06 & Good \\
\hline & & & $\begin{array}{l}\text { 3. Good quality, clean, and } \\
\text { selected raw materials and } \\
\text { spices. }\end{array}$ & 4,18 & Good \\
\hline \multirow[t]{4}{*}{4.} & & 4,22 & 1. Design of dining area & 4,36 & Very good \\
\hline & atmosphere & (good) & 2. Privacy and noise levels & 4,10 & Good \\
\hline & of restaurant & & 3. Atmosphere of the dining room & 4,30 & Very good \\
\hline & & & $\begin{array}{l}\text { 4. Additional facilities such as } \\
\text { free wifi access and music }\end{array}$ & 4,12 & Good \\
\hline
\end{tabular}

Sources: data tabulation (2017) 


\section{Average Rate of Overall Satisfaction}

Average rate of overall tourist satisfaction described as follows: (1) Food quality factor obtained a very good score with mean 4.24; (2) Price factor obtained a good score with mean 3.42 ; (3) Cleanlines (hygiene and sanitation) factor obtained a good score with mean 4.17; 4) Atmosphere factor get a very good score with mean of 4.22.

\section{E. Dominant Factors Influence Tourists Satisfaction}

Based on the results of data processing, the dominant factors affecting tourists satisfaction towards traditional Balinese cuisine at restaurant in Ubud area, are: (1) Food quality factor consisting of presentation or appearance and the unique taste of traditional Balinese cuisine; (2) The atmosphere of restaurant factor, consisting of the design and dining room atmosphere; and (3) Cleanlines Factor (hygiene and sanitation).

\section{F. Conformity Analysis}

If the performance score is greater than the important score, this means that the performance of traditional Balinese cuisine to tourists in Ubud area is of good quality. In percentage, the level of conformity in this condition is greater than $100 \%$. This condition is desired by tourists.

If the performance score is less than the degree of important score, this means that the performance of traditional Balinese cuisine has not met the expectations of tourists. If the score of performance is equal to the score of the degree of importance means that tourists expectation can be fulfilled, which is often referred to as balanced condition (Equilibrium). This condition illustrates that consumers do not feel experiencing "excees and shortage satisfaction". This condition is an ideal condition for both parties (restaurants that sell Balinese cuisine with tourists as consumers) where the level of conformity of this condition is $100 \%$.

Based on Table 6, it is apparent that of the sixteen elements of service performance that determine the satisfaction of tourists, there are fourteen elements that have a level of conformity equal to or above $100 \%$ and there are two variables that have a level of conformity below $100 \%$. This data means that from sixteen traditional Balinese food variables, there are fourteen variables that have good and excellent quality, and two variables that have neutral or medium quality.

TABLE VI. COMPATIBILITY BETWEEN DEGREE OF IMPORTANT AND PERFORMANCE RATE OF TRADITIONAL BALINESE CUISINE IN UBUD TOURISM RESORT.

\begin{tabular}{llccc}
\hline \multirow{2}{*}{ No. Satisfaction Attribut } & \multicolumn{3}{c}{ Score } & Conformt \\
\cline { 3 - 4 } & & $\mathrm{X}$ & $\mathrm{Y}$ & $(\%)$ \\
\hline 1 & The unique taste of traditional Balinese cuisine & 228 & 224 & 102,87 \\
2 & The aroma or flavors & 228 & 224 & 102,87 \\
3 & The portion size & 220 & 220 & 100,00 \\
4 & The selection of menu choices & 215 & 220 & 97,73 \\
5 & The Presentation of menu & 217 & 220 & 98,64 \\
6 & Affordable price offered & 222 & 222 & 100,00 \\
7 & The presence of special package food prices such as cheap price & 170 & 188 & 91,88 \\
& packages & & & \\
8 & The special offer of promotional packages such as "buy one get & 168 & 196 & 89,46 \\
& one free" & & & \\
9 & Value for money & 211 & 208 & 101,52 \\
10 & Hygiene presenting and serving & 223 & 230 & 97,29 \\
11 & Hygiene preparation and cooking process & 223 & 230 & 97,29 \\
12 & good quality, clean, and selected raw materials and spices & 229 & 220 & 104,54 \\
13 & The design of the dining room & 226 & 217 & 104,15 \\
14 & Privacy and noise levels & 226 & 227 & 99,35 \\
15 & The dining room atmosphere & 230 & 226 & 102,56 \\
16 & Additional facilities such as free wifi access and music & 230 & 225 & 103,55 \\
& $\quad$ Means & 2.791 & 2.837 & 102,45 \\
\hline
\end{tabular}

$\begin{array}{rll}\text { Notes :X } & = & \text { Performance rate } \\ \mathrm{Y} & = & \text { Degree of important }\end{array}$


Based on Table 6 it appears that from 16 attributes or performance variables of Balinese cuisine to tourists in Ubud area, there are seven (7) variables that the conformity level is under $100 \%$. Increased performance is required especially on factors that have a level of conformity below $100 \%$.

\section{G. The Importance-Performance Analysis}

Analysis of Cartesian diagram in determining its position, first calculated average attribute performance level and level of importance. The next calculation is to calculate the average of the average level of performance or satisfaction and importance level. The average attribute performance level and importance level of satisfaction determinants are presented in Table VII underneath.

TABEL VII. AVERAGE RATE OF DEGREE OF IMPORTANT AND PERFORMANCE OF BALINESE CUISINE IN UBUD TOURISM RESORT.

\begin{tabular}{llcc}
\hline \multirow{2}{*}{ No. } & Performance of Determinant Factor towards Satisfaction & \multicolumn{2}{c}{ Means } \\
\cline { 3 - 4 } & & $\mathrm{X}$ & $\mathrm{Y}$ \\
\hline 1 & The unique taste of traditional Balinese cuisine & 4,33 & 4,53 \\
2 & The aroma or flavors & 4,08 & 4,28 \\
3 & The portion size & 4.16 & 4,16 \\
4 & The selection of menu choices & 4,19 & 3,89 \\
5 & The Presentation of menu & 4,45 & 4,28 \\
6 & Affordable price offered & 3,98 & 3,98 \\
7 & The presence of special package food prices such as cheap & 2,78 & 3,90 \\
& price packages & & \\
8 & The special offer of promotional packages such as "buy one get & 2,57 & 3,90 \\
& one free" & 4,33 & 4,25 \\
9 & Value for money & 4,28 & 4,58 \\
10 & Hygiene presentation and serving & 4,06 & 4,26 \\
11 & Hygiene preparation and cooking process & 4.18 & 4,06 \\
12 & Good quality, clean, and selected raw materials and spices & 4,36 & 4,12 \\
13 & The design of the dining room & 4,10 & 4,17 \\
14 & Privacy and noise levels & 4.30 & 4,20 \\
15 & The dining room atmosphere & 4,12 & 3,88 \\
16 & Additional facilities such as free wifi access and music & 4,01 & 4,15 \\
\hline
\end{tabular}

Notes:

$\mathrm{X}=$ Performance rate

$\mathrm{Y}=$ Degree of important

Based on the data presented in Table 7, the average rate of the performance or satisfaction towards sixteen (16) variables ranged from 3.88 (lowest) to 4.45 (highest) while the average interest rate variables ranged from 3.57 (lowest) to 4.53 (highest). Table 7 also shows that average performance results (tourist satisfaction) is 4.01 and the average degree of importance is 4.15 .

Based on Cartesian diagram in Figure 3, the location of the relationship between the performance or satisfaction with the degree of importance according to the perception of tourists is in quadrant $\mathrm{B}$, $\mathrm{C}$ and D. 


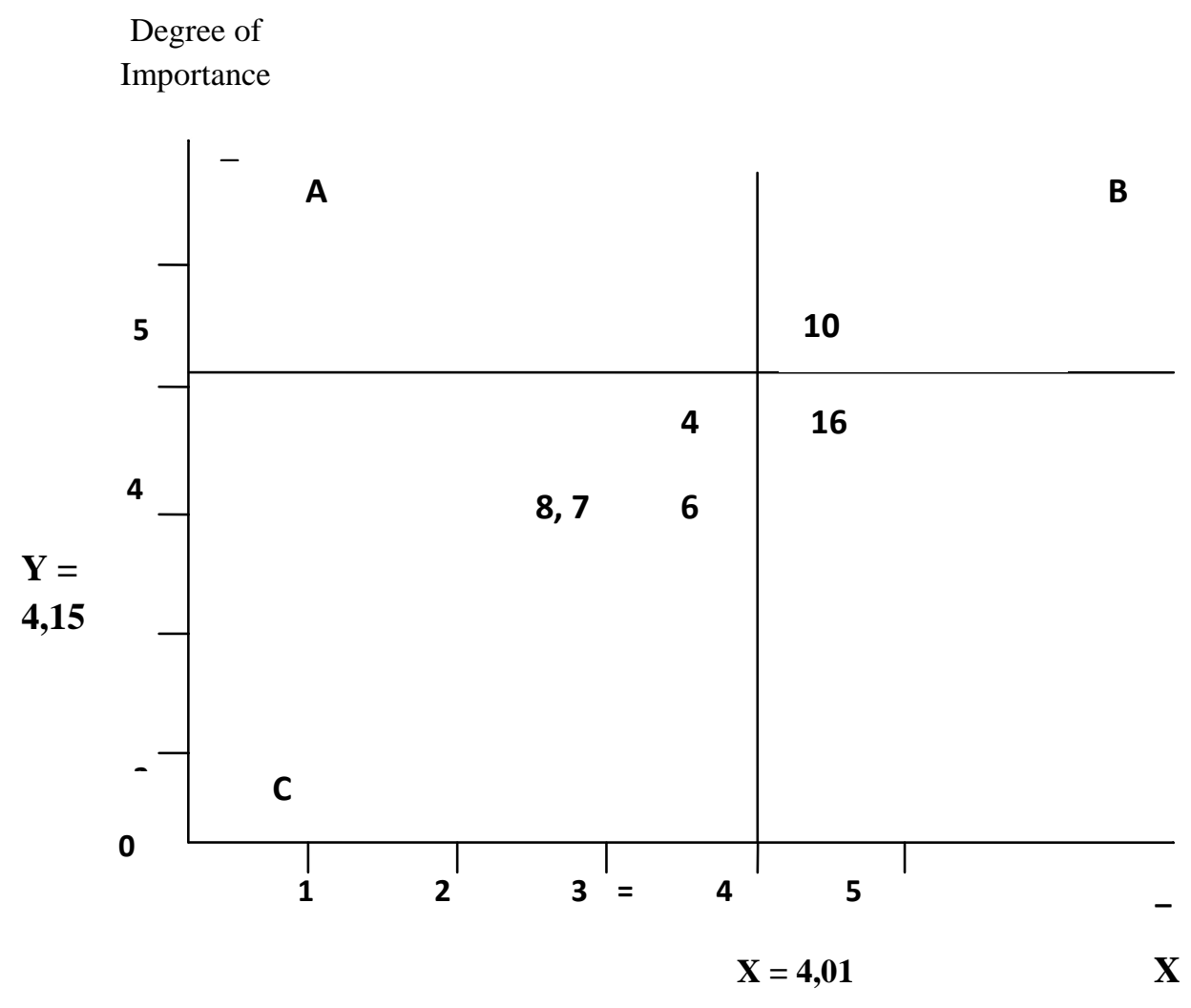

FIG II. CARTESIAN DIAGRAM

Determinant factors affect Tourist Satisfaction owards Traditional Balinese Cuisine at Restaurants in Ubud Tourism Area, Gianyar were presented on each quadrant is as follows:

1. Quadrant A

Indicating the attributes of travelers' satisfaction towards Balinese cuisine at restaurants in Ubud Tourism resort is an important attribute for tourists, but restaurant management has not been implemented according to tourists' wishes. No attribute marked in Quadrant A.

2. Quadrant B

The satisfaction attribute that is in Quadrant B is a factor that is considered very important for tourists and its performance is very satisfying. This condition should be maintained by the management of restaurants that offer traditional Balinese cuisine. Quadrant B consists of eleven (11) attributes, such as: (a) The unique taste of traditional Balinese cuisine (1); (b) The aroma or flavors (2); (c) Portion size (3); (d) (e) Presentation of menu (5); (f) Value for money (9); (g) Hygiene presenting and serving (10); (h) Hygiene preparation and cooking process (11); (i) Good quality, clean, and selected raw materials and spices (12); (j) The design of the dining room (13); (k) Privacy and noise levels (14), and ; (1) dining room atmosphere (15).

3. Quadrant C

Attributes that are in the $\mathrm{C}$ quadrant were less important for tourists, which in the implementation by the restaurant manager gets very low attention, so that less satisfy restaurant's customers. Quadrant C consists of four (4) attributes, such as: (a) The selection of menu choices (4); (b) Affordable price offered (6); (c) The presence of special package food prices such as cheap price packages (7); (d) The special offer of promotional packages such as "buy one get one free" (8)

4. Quadrant D

Shows the factors of consumer satisfaction that are not important to costumers, but in the execution by the management of restaurant gets excessive priority so it is very satisfying tourists. Quadrant D consists of one attribute: Additional facilities such as free wifi access and music (16). 


\section{CONCLUSION}

Based on the analysis and discussion described in the previous chapters, the conclusion of this research is summarized as follows:

The average performance of tourist satisfaction on traditional Balinese cuisine at restaurant in Ubud Tourism Resort, Gianyar is as follows: (1) The food quality is very good, (2) The price performs well; (3) Cleanliness (hygiene and sanitation) performs well; (4) The atmosphere of restaurant performs very well.

Average rate of overall tourist satisfaction towards traditional Balinese cuisine at restaurant in Ubud, Gianyar is good category. The dominant factors affecting the satisfaction of tourists are food quality and the atmosphere of restaurant. The determinant factors affecting tourist satisfaction towards traditional Balinese cuisine at restaurant can be classified into two groups, such as high and low importance.

The high importance level consists of attributes: (1) The unique taste of traditional Balinese cuisine; (2) The aroma or flavors of traditional Balinese cuisine; (3) Portion size; (4) Presentation of menu; (5) Value for money; (6) Hygiene presenting and serving; (7) Hygiene preparation and cooking process; (8) Good quality, clean, and selected raw materials and spices; (9) The design of the dining room; and (10) Privacy and noise levels. On the other hand, attributes with low degree of important consist of: (1) The selection of menu choices; (2) Affordable price offered; (3) The presence of special package food prices such as cheap price packages; (4) The special offer of promotional packages such as "buy one get one free"; (5) Additional facilities such as free wifi access and music; and (6) dining room atmosphere.

Next, attributes with low degree of important consist of attributes: (1) The selection of menu choices; (2) Affordable price offered; (3) The presence of special package food prices such as cheap price packages; (4) The special offer of promotional packages such as "buy one get one free"; (5) Additional facilities such as free wifi access and music; and (6) dining room atmosphere.

Furthermore, tourists assessment on satisfaction attributes also consists of two groups, such as attributes whose performance has met tourist's expectations and attributes whose performance has not met tourist's expectation. Attributes whose performance has met the expectations of tourists consists of: (1) The unique taste of traditional Balinese cuisine; (2) The aroma or flavors; (3) Portion size, 4) Presentation of menu, (5) Value for money; (6) Hygiene presentation and serving; (7) Hygiene preparation and cooking process; (8) Good quality, clean, and selected raw materials and spices; 9) The design of the dining room; (10) Privacy and noise levels; and (11) dining room atmosphere. And last, attributes whose performance has not met the tourists expectations consists of: (1) The selection of menu choices; (2) Affordable price offered; (3) The presence of special package food prices such as cheap price packages; (4) The special offer of promotional packages such as "buy one get one free"; (5)Additional facilities such as free wifi access and music.

\section{REFERENCES}

Abdullah, D.,N.,M.,A. Rozario, F. (2009). Influence of Service and Product Quality towards ABI/INFORM GLOBAL. USA.

Academy of Science, Engineering and Technology 53 - 2009.

Administration Quarterly. June 2000; 41,3 : ABI/INFORM GLOBAL. USA.

Andaleeb, S.,S. Conway,C. 2006. Customer Satisfaction in the Restaurant Industry: An

Bozorgi, M. 2007. Measuring Service Quality in The Airline Using SERVQUAL Model (Case of IAA). Department of Business Administration and Social Sciences. Division of Industrial Marketing And E-Commerce. Lulea University of Technology. Iran.

Consumers. Cornell Hotel and Restaurant Administration Quarterly; August 2003: 44, 49

Cousins, J., Foskett, D., Gillespie, C. 2002. Food and Beverage Management. London:

Customer Satisfaction: A Case Study at the Staff Cafetaria in the Hotel Industry. World

Dalem, K.P, 2010. Strategi Pengembangan Makanan Tradisional Bali pada Freestanding

Dogdubay, M. Avcikurt, C. 2008. Customer Loyalty in the Speciality Restaurants: An example from Istanbul. Balikesir University, Turkey. murat_dogdubay@yahoo.com 
examination of the transaction-specific model. Journal of Service Marketing. The Behrend College, Erie, Pennsylvania,USA.

Hsu, C. H. C. Dan Powers, T. 2002. Marketing Hospitality. Third Edition. John Wiley \& Son, Inc: New York.

International Journal of Contemporary Hospitality Management. 9 (3), 116-123.

Kabupaten Badung, Bali. Magister Kajian Pariwisata, Universitas Udayana, Bali.

Karangasem and Jembrana Bali. Universitas Udayana, Bali

Kivela, J. 1997. Restaurant Marketing Selection and Segmentation in Hong Kong.

Magister Kajian Pariwisata. Universitas Udayana, Bali

Moschis, G., Curasi, C., Bellenger, D. 2003. Restaurant - Selection Preferences of Mature of Contemporary Hospitality management; 2003 ; 15, 1 ABI/INFORM GLOBAL.USA.

Oh. H. Dinner Perception of Quality, Value, and Satisfaction. Cornell Hotel and Restaurant Pasar. Jakarta: Rineka Cipta.

Prentice Hall/Pearson Education.

Putri, (2010). Eksistensi dan Esensi Makanan Tradisional Bali Sebagai Penunjang Culinary

Restaurant di Kelurahan Tanjung Benoa, Kecamatan Kuta Selatan, Kabupaten Badung,

Sparks, B., Bowen, J., klag, S. 2003. Restaurant and The Tourist Market. International Journal

Suastuti, N.,L. 2011. Persepsi Wisatawan Mancanegara terhadap industri restoran di

Sujaya, 2013. Safety of Balinese Ethnic Foods: A case Study on Dearrhea Outbreak in

Supranto, J. 2001. Pengukuran Tingkat Kepuasan Pelanggan Untuk Menaikkan Pangsa

Tourism di Kabupaten Badung. Universitas Udayana, Bali 